\title{
Long Term Effect of Manure and Fertilizers on Depthwise Distribution of Total Zn, Cu, Fe and Mn under Rice-Wheat System
}

\author{
M.K. Dhaliwal ${ }^{1}$, S.S. Dhaliwal ${ }^{2 *}$ and A.K. Shukla ${ }^{3}$ \\ ${ }^{1}$ Department of Soil and Water Conservation, Punjab \\ ${ }^{2}$ Punjab Agricultural University, Ludhiana- 141004 \\ ${ }^{3}$ Indian Institute of Soil Science, Bhopal, Madhya Pradesh
}

*Corresponding author

\section{A B S T R A C T}

Keywords

Total $\mathrm{Zn}, \mathrm{Cu}, \mathrm{Fe}$ and $\mathrm{Mn}$, Biogas

slurry manure,

Chemical fertilizers,

Rice-wheat system

Article Info

Accepted:

22 December 2018

Available Online:

10 January 2019
Laboratory analysis was made on the soil samples collected (October 2013) from an on-going long-term field experiment (in progress since Kharif 2009-10) at Department of Soil Science, PAU, Ludhiana to investigate the effect of manure and chemical fertilizers in rice (Oryza sativa L.) - wheat (Triticum aestivum L.) system. The organic manure through bio gas slurry (BGS) @ $6 \mathrm{t} \mathrm{ha}^{-1}$ was incorporated along with nitrogen fertilizer (N@80 and $120 \mathrm{~kg} \mathrm{ha}^{-1}$ ), phosphorus fertilizer ( $\left.\mathrm{P} @ 30 \mathrm{~kg} \mathrm{ha}^{-1}\right)$ and potassium fertilizer $\left(\mathrm{K} @ 30 \mathrm{~kg} \mathrm{ha}^{-1}\right)$ to the rice crop. The results of our study reported that the total $\mathrm{Zn}$ decreased with increase in soil depth, whereas the increased concentration of total $\mathrm{Cu}, \mathrm{Fe}$ and $\mathrm{Mn}$ was observed at lower soil depths. Higher concentration of total $\mathrm{Zn}, \mathrm{Cu}, \mathrm{Fe}$ and $\mathrm{Mn}$ was also found in the treatments where organic manure (BGS) was added @ $6 \mathrm{t}$ $\mathrm{ha}^{-1}$ along with $\mathrm{N} @ 80 \mathrm{~kg} \mathrm{ha}^{-1}$ and $\mathrm{K} @ 30 \mathrm{~kg} \mathrm{ha}^{-1}$ to the rice crop. The results of this study were of practical utility since application of manure and chemical fertilizers together increased total $\mathrm{Zn}, \mathrm{Cu}, \mathrm{Fe}$ and $\mathrm{Mn}$ in the surface soil whereas, their concentrations decreased with depth.

\section{Introduction}

Rice (Oryza sativa L.) - wheat (Triticum aestivum L.) is the predominant cropping system, being practiced by majority of farmers in different agro-climatic zones of Punjab. Production of food grains is increasing year after year due to intensive cultivation of land thereby depleting a huge amount of macronutrients along with micronutrients. Relatively, over use of macronutrient fertilizers, decreased use of organic manures, reduced recycling of crop residues, and bumper harvests in the past three decades have induced secondary and micronutrient deficiencies in the Indo Gangetic Plains. Dhaliwal and Walia (2008) reported that incorporation of manures in the soil has beneficial effect on soil health by improving physico-chemical properties besides supplying the micronutrients like $\mathrm{Zn}, \mathrm{Cu}, \mathrm{Fe}$ and $\mathrm{Mn}$. Herencia et al., (2008) reported that with the 
addition of organic and mineral fertilization, OM-bound fractions of micronutrients increased their availability and uptake in the soil. Singhet al., (1988) reported that Fe and $\mathrm{Mn}$ associated with organic matter (OMbound fraction) increased with application of manure, which increased the yield under ricewheat system. However, Sharma et al.,(2004) reported the decrease of total fraction with green manure after the harvest of wheat which could be due to an increase in the water soluble plus exchangeable fraction as well as held on inorganic sites. In a field experiment, Behera et al., (2008) reported the distribution of total micronutrient, $\mathrm{Zn}$ fractions and their contribution toward availability and plant uptake of $\mathrm{Zn}$ under long-term maize-wheat cropping in an inceptisol. Dhaliwal et al., (2011) reported distribution of total micronutrient fractions and their contribution towards availability and plant uptake of micronutrient under long term maize-wheat cropping sequence indicated residual micronutrients as the dominant proportion of total $\mathrm{Zn}$ and $\mathrm{Cu}$. Zhang et al., (2008) observed the long term effect of manure application on micronutrients availability under rice-wheat and maize-wheat cropping systems. They reported that the DTPAextractable $\mathrm{Zn}$ and $\mathrm{Cu}$ availability was higher in maize-wheat cropping system as compared to rice-wheat cropping system. Distribution of total $\mathrm{Zn}, \mathrm{Cu}, \mathrm{Fe}$ and $\mathrm{Mn}$ and their contribution towards availability and plant uptake under long-term maize-wheat system was reported by Agbenin and Henningsen (2003) who indicated that the residual micronutrient fraction as the dominant portion of total $\mathrm{Zn}$, $\mathrm{Cu}, \mathrm{Fe}$, and $\mathrm{Mn}$ fraction. Similarly, Behera et al., (2008 \& 2009) reported the distribution of total $\mathrm{Zn}$ fraction and their contribution toward availability and plant uptake of $\mathrm{Zn}$ under longterm maize-wheat cropping in an Inceptisol. Singh et al., (1988) reported the distribution of total $\mathrm{Zn}, \mathrm{Cu}, \mathrm{Fe}$ and $\mathrm{Mn}$ and their fractions in soils. In sequential extraction scheme which fractionated $\mathrm{Zn}, \mathrm{Cu}, \mathrm{Fe}$ and $\mathrm{Mn}$ into exchangeable, carbonates-bound, organically bound, Mn-oxide-bound, amorphous Fe-oxide bound, crystalline Fe-oxide bound, residual forms. It has been further reported that about $82,62,52$ and $53 \%$ of the total soil $\mathrm{Zn}, \mathrm{Cu}$, $\mathrm{Fe}$, and $\mathrm{Mn}$ respectively, was associated with residual fraction whereas, 17, 17, 41 and 11\% of the total $\mathrm{Zn}, \mathrm{Cu}, \mathrm{Fe}$ and $\mathrm{Mn}$ respectively was associated with the crystalline Fe-oxide bound fraction. Green manure and soil applied Mn to rice-wheat system increased the DTPA-extractable, water soluble plus exchangeable and Mn specifically adsorbed on the inorganic sites whereas, Mn held on organic sites and oxide bound surfaces decreased due to their conversion to other forms (Dhaliwal et al., 2008). The vertical distribution of micronutrients was observed by Verma et al., (2005a and 2005b) in different soil profiles on different physiographic units in central Punjab which reported higher content of micronutrient in fine textured soils of old flood plain and lower content in sandy soils. They further reported that DTPA $-\mathrm{Zn}$, $\mathrm{Cu}$ and $\mathrm{Fe}$ decreased with increase in soil depth but DTPA - Mn did not follow a definite trend.

Various research studies revealed that application of manure in combination with chemical fertilizers increased the OC level and available macro as well as micronutrients in soil. The information on surface and depth wise distribution of available micronutrients with application of manure and fertilizers is meager in rice-wheat system. Also the information of micronutrient fractions in the system is lacking and the effect of manure and fertilizers on physico-chemical properties of soil under this system needs to be investigated. Taking these points into consideration the research has been conducted to study the depth wise variation of total $\mathrm{Zn}, \mathrm{Cu}, \mathrm{Fe}$ and $\mathrm{Mn}$ in soils under rice-wheat system. 


\section{Materials and Methods}

\section{Experimental site and treatment details}

In order to achieve the objectives mentioned earlier, laboratory studies were made on the soil samples collected from an on-going longterm experiment on role of manure and fertilizers in rice-wheat cropping system (in progress since Kharif 2009-10) at Department of Soil Science, Punjab Agricultural University, Ludhiana. The soil of experiment field was classified as Typic Ustochrept. The experiment was conducted in a fixed layout since its beginning with treatments combinations mentioned in Table 1. Each treatment was replicated thrice in a plot size of $11 \times 6 \mathrm{~m}^{2}$. The experiment was laid out in a split plot design with four main and three sub treatments. The organic manure through bio gas slurry (BGS) @ $6 \mathrm{t} \mathrm{ha}^{-1}$ was incorporated along with nitrogen fertilizer (N @ 80 and 120 $\mathrm{kg} \mathrm{ha}^{-1}$ ), phosphorus fertilizer (P @ $30 \mathrm{~kg} \mathrm{ha}^{-1}$ ) and potassium fertilizer ( $\mathrm{K} @ 30 \mathrm{~kg} \mathrm{ha}^{-1}$ )were applied to the rice crop. Whereas in wheat crop, nitrogen fertilizer ( $\mathrm{N} @ 120 \mathrm{~kg} \mathrm{ha}^{-1}$ ), different levels of phosphatic fertilizer (P @ 30 and $\left.60 \mathrm{~kg} \mathrm{ha}^{-1}\right)$ and potassium fertilizer ( $\mathrm{K}$ @ $30 \mathrm{~kg} \mathrm{ha}^{-1}$ ) were applied.

Various physico-chemical properties of the experimental soil are given in Table 2 . The $\mathrm{pH}$ of the soil was 6.01 and the EC was $0.17 \mathrm{dS}$ $\mathrm{m}^{-1}$. The soil organic carbon was $0.33 \%$, available nitrogen content was $275 \mathrm{~kg} \mathrm{ha}^{-1}$, available phosphorus was $23 \mathrm{~kg} \mathrm{ha}^{-1}$ and available potassium was observed as $184 \mathrm{~kg}$ $\mathrm{ha}^{-1}$. The concentration of $\mathrm{Zn}, \mathrm{Cu}, \mathrm{Fe}$ and $\mathrm{Mn}$ was noted as $1.76,0.67,5.87$ and $4.59 \mathrm{mg}$ $\mathrm{kg}^{-1}$.

\section{Treatment details}

The experiment consists of 12 treatments with three replications under split plot design (Table 1). Biogas manure was applied @6 t $\mathrm{ha}^{-1}$ before transplantation of rice with different combinations of nitrogen and phosphorus fertilizers were applied to rice and wheat crops. Similarly, profile samples from six periodic depths $(0-15,15-30,30-60,60-90$, $90-120,120-150 \mathrm{~cm}$ ) were collected after harvesting of rice in the month of October, 2013. Soil samples were analyzed for DTPAextractable and total $\mathrm{Zn}, \mathrm{Cu}, \mathrm{Fe}$ and $\mathrm{Mn}$.

\section{Laboratory analysis}

\section{Total $\mathrm{Zn}, \mathrm{Cu}, \mathrm{Fe}$ and $\mathrm{Mn}$}

For total elemental analysis of $\mathrm{Zn}, \mathrm{Cu}, \mathrm{Fe}$ and $\mathrm{Mn}$, a $0.5 \mathrm{gm}$ sample of soil was digested with $5 \mathrm{ml}$ of hydrofluoric acid (HF), $1.0 \mathrm{ml}$ of perchloric acid $\left(\mathrm{HClO}_{4}\right)$ and 5-6 drops of nitric acid $\left(\mathrm{HNO}_{3}\right)$ in a $30 \mathrm{ml}$ capacity platinum crucibles (Page et al., 1982). When the soil became completely dry in the crucible the residue in the crucible was completely dissolved in $5 \mathrm{ml}$ of $6 \mathrm{~N} \mathrm{HCl}$.

The contents of the crucible were transferred to $100 \mathrm{ml}$ volumetric flask with double distilled water. The digests were analyzed for total $\mathrm{Zn}, \mathrm{Cu}, \mathrm{Fe}$ and $\mathrm{Mn}$ after appropriate dilutions. The results of the elemental analysis were reported on an oven-dry weight basis.

\section{Laboratory analysis}

Different parameters pertaining to analysis of soil were subjected to split plot block design analysis of variance. Critical difference (CD) was used to compare the treatment effects at $\mathrm{P}<0.05$. The statistical analysis was done with the help of method described by Panse and Sukhatme (1985).

\section{Results and Discussion}

The soil samples collected after harvesting of rice from an ongoing long term experiment were subjected to estimation for total micronutrients viz. $\mathrm{Zn}, \mathrm{Cu}, \mathrm{Fe}$ and $\mathrm{Mn}$. 


\section{Depthwise distributions of total Zn}

The data presented in Table 3 showed the distribution of total $\mathrm{Zn}$ in profile soil $(0-150$ $\mathrm{cm})$ samples collected after harvesting of rice crop. The data revealed that the higher concentrations of total $\mathrm{Zn}$ were observed in surface soil as compared to subsurface soil. Normally the total $\mathrm{Zn}$ decrease with increase in soil depth under rice-wheat cropping system.

The content of total $\mathrm{Zn}$ in surface soil (0-15 $\mathrm{cm}$ ) ranged from 46.47 to $55.70 \mathrm{mg} \mathrm{kg}^{-1}$ in all the treatments. It was found significantly higher in surface soil where organic manure has been added along with the chemical fertilizers whereas in subsurface layers at 15 $30,30-60,60-90,90-120$ and $120-150 \mathrm{~cm}$ soil depths, the concentrations of total $\mathrm{Zn}$ decreased, ranged from 27.87 to $36.30,20.60$ to $29.37,20.10$ to $26.97,21.07$ to 28.27 and 22.17 to $29.47 \mathrm{mg} \mathrm{kg}^{-1}$ which may be due to higher organic matter present in surface soil as compare to subsurface soil.

The concentration decreases upto $90-120 \mathrm{~cm}$ soil depth and then it increased at $120-150 \mathrm{~cm}$ soil depth. Significantly higher concentration of total $\mathrm{Zn}$ was observed in the treatments where organic manure @ $6 \mathrm{t} \mathrm{ha}^{-1}$ has been incorporated along with $\mathrm{N} @ 80 \mathrm{~kg} \mathrm{ha}^{-1}$ and $\mathrm{P}_{2} \mathrm{O}_{5} @ 30 \mathrm{~kg} \mathrm{ha}^{-1}$ applied to the rice crop as compared to the treatments where only N @ $120 \mathrm{~kg} \mathrm{ha}^{-1}$ was applied without application of organic manure and $\mathrm{P}_{2} \mathrm{O}_{5}$ to the rice crop. Similarly, significant increased concentration of total $\mathrm{Zn}$ was also noticed in the treatments where organic manure @ 6 t ha ${ }^{-1}$ was incorporated along with $\mathrm{N} @ 80 \mathrm{~kg} \mathrm{ha}^{-1}$ without the application of phosphatic fertilizer as compared to the treatments $\mathrm{N} @ 120 \mathrm{~kg}$ ha $^{-1}$ and $\mathrm{P}_{2} \mathrm{O}_{5} @ 30 \mathrm{~kg} \mathrm{ha}^{-1}$ were applied to the rice crop without addition of organic manure. The significant increase in the concentration of total $\mathrm{Zn}$ in the treatments where organic manure @ $6 \mathrm{tha}^{-1}$ was added along with $\mathrm{N} @$ $80 \mathrm{~kg} \mathrm{ha}^{-1}$ and $\mathrm{P}_{2} \mathrm{O}_{5} @ 30 \mathrm{~kg} \mathrm{ha}^{-1}$ applied to the rice crop as compared to the treatments where no organic manure was incorporated, only $\mathrm{N} @ 120 \mathrm{~kg} \mathrm{ha}^{-1}$ and $\mathrm{P}_{2} \mathrm{O}_{5} @ 30 \mathrm{~kg} \mathrm{ha}^{-1}$ were applied. Whereas in the wheat crop, the different levels of $\mathrm{P}_{2} \mathrm{O}_{5}\left(0,30\right.$ and $\left.60 \mathrm{~kg} \mathrm{ha}^{-1}\right)$ were applied, significant results in concentration of total $\mathrm{Zn}$ has been observed with increase in levels of phosphatic fertilizer. The interaction between rice and wheat crop is observed as non significant.

\section{Depth wise distribution of total $\mathrm{Cu}$}

Higher concentration of total $\mathrm{Cu}$ was observed in the surface soil samples under the rice-wheat cropping system as compared to the subsurface soil samples (Table 4). The concentration of total $\mathrm{Cu}$ ranged from 7.20 to $9.43 \mathrm{mg} \mathrm{kg}^{-1}$ in surface soil $(0-15 \mathrm{~cm})$. The total $\mathrm{Cu}$ increased with increased in soil depth but its concentration start decreasing with increase in depth. The concentration for total $\mathrm{Cu}$ ranged from 7.68 to $10.32,8.43$ to $9.87,8.97$ to $9.93,8.77$ to 9.87 and 8.73 to $9.93 \mathrm{mg} \mathrm{kg}^{-1}$ in $15-30,30-60,60-90,90-120$ and $120-150 \mathrm{~cm}$ soil depth, respectively. Among the different treatments, a significant increase in total $\mathrm{Cu}$ was noticed in the treatments where organic manure @ $6 \mathrm{t} \mathrm{ha}^{-1}$ has been incorporated along with $\mathrm{N} @ 80 \mathrm{~kg}$ $\mathrm{ha}^{-1}$ and $\mathrm{P}_{2} \mathrm{O}_{5} @ 30 \mathrm{~kg} \mathrm{ha}^{-1}$ to the rice crop as compared to the treatments where only $\mathrm{N}$ @ $120 \mathrm{~kg} \mathrm{ha}^{-1}$ was applied without $\mathrm{P}_{2} \mathrm{O}_{5}$ and organic manure application to the rice crop. Significantly higher concentration of total $\mathrm{Cu}$ was also noticed in the treatments where organic manure@6 tha ${ }^{-1}$ was applied along with N@80 kg ha ${ }^{-1}$ without the application of phosphatic fertilizer as compared to the treatments where $\mathrm{N} @ 120 \mathrm{~kg} \mathrm{ha}^{-1}$ and $\mathrm{P}_{2} \mathrm{O}_{5}$ @ $30 \mathrm{~kg} \mathrm{ha}^{-1}$ were applied without organic manure addition to the rice crop. In the wheat crop, where the different levels of $\mathrm{P}_{2} \mathrm{O}_{5}\left(0,30\right.$ and $\left.60 \mathrm{~kg} \mathrm{ha}^{-1}\right)$ were applied, a 
significant response has been observed in concentration of total $\mathrm{Cu}$ at these levels of phosphatic fertilizer. The interaction between rice and wheat treatments was also observed as significant. This increase in availability of total $\mathrm{Cu}$ in the plots which were treated organically along with chemical fertilizers may be due to reduction in the redox - potential of the soil with the addition of organic manures which lead to more release of micronutrients in an available form in the soil as compared to the application of chemical fertilizer alone. It was observed that total $\mathrm{Cu}$ remained insignificant at lower soil depths and the interaction between the two treatments also found to be non significant.

\section{Depthwise distribution of total Fe}

The data presented in Table 5 showed the distribution of total $\mathrm{Fe}$ in soil profile $(0-150$ $\mathrm{cm})$ samples collected after harvesting of rice. The results revealed that concentrations of total Fe ranged from 1.25 to 1.51 per cent in surface soil $(0-15 \mathrm{~cm})$ and these concentrations further increased with increase in soil depths. It was observed that the total $\mathrm{Fe}$ concentration varied from 1.40 to 1.55 , 1.45 to $1.65,1.57$ to $1.73,1.56$ to 1.74 and 1.64 to $1.81 \%$ in $15-30,30-60,60-90,90-$ 120 and $120-150 \mathrm{~cm}$ soil depth, respectively.

Significantly higher level of total $\mathrm{Fe}$ was reported in the treatments where organic manure@6 t ha ${ }^{-1}$ has been incorporated along with $\mathrm{N} @ 80 \mathrm{~kg} \mathrm{ha}^{-1}$ and $\mathrm{P}_{2} \mathrm{O}_{5} @ 30 \mathrm{~kg} \mathrm{ha}^{-1}$ to the rice crop as compared to the treatments where N@120 kg ha ${ }^{-1}$ was applied without organic manure and $\mathrm{P}_{2} \mathrm{O}_{5}$ application to the rice crop. Significantly higher concentration of total $\mathrm{Fe}$ was also noticed in the treatments where organic manure @ $6 \mathrm{t} \mathrm{ha}^{-1}$ was added along with $\mathrm{N} @ 80 \mathrm{~kg} \mathrm{ha}^{-1}$ without the application of phosphatic fertilizer as compared to the treatments where N@120 kg $\mathrm{ha}^{-1}$ and $\mathrm{P}_{2} \mathrm{O}_{5} @ 30 \mathrm{~kg} \mathrm{ha}^{-1}$ were applied to the rice crop without addition of organic manure. On the other hand in the wheat crop, where the different levels of $\mathrm{P}_{2} \mathrm{O}_{5}\left(0,30\right.$ and $\left.60 \mathrm{~kg} \mathrm{ha}^{-1}\right)$ were applied, a significant response has been observed in concentration of total $\mathrm{Fe}$ at these levels of phosphatic fertilizer. Higher content of total Fe was observed which may be due to the effect of submergence and may be further associated with more organic matter present in surface soil. Similar results were observed by Khan et al., (2002), who reported the higher concentration of total $\mathrm{Fe}$ in surface $(0-15 \mathrm{~cm})$ as compared to the subsurface layers under rice-wheat system. Similarly, Elbordiny and Camilia (2008) reported that the significantly positive correlation of total $\mathrm{Fe}$ with organic matter content in surface and subsurface soil. The interaction between rice and wheat crop treatments is also observed as significant.

\section{Depthwise distributions of total Mn}

The total Mn concentration in surface soil ( 0 $15 \mathrm{~cm})$ ranged from 203.6 to $219.8 \mathrm{mg} \mathrm{kg}^{-1}$ under rice-wheat cropping system (Table 6). The total Mn increased with increase in soil depth. It varied from 285.5 to $305.3,297.2$ to $326.4,316.5$ to $345.3,332.7$ to 360.9 and 363.6 to $386.5 \mathrm{mg} \mathrm{kg}^{-1}$ at $15-30,30-60,60-$ 90, 90-120 and 120-150 cm soil depths, respectively. The level of total $\mathrm{Mn}$ at lower depths was higher may be due to submergence and it leached down to lower layers. The data reported the significant increase in the concentration of total $\mathrm{Mn}$ in the treatments where organic manure@6t ha $^{-1}$ has been added along with N@80 kg ha ${ }^{-}$ ${ }^{1}$ and $\mathrm{P}_{2} \mathrm{O}_{5} @ 30 \mathrm{~kg} \mathrm{ha}^{-1}$ which were applied to the rice crop as compared to the treatments where only $\mathrm{N} @ 120 \mathrm{~kg} \mathrm{ha}^{-1}$ was applied without organic manure and $\mathrm{P}$ fertilizer application.

Significantly higher concentration of total Mn was also noticed in the treatments where 
organic manure@6 tha ${ }^{-1}$ was incorporated along with $\mathrm{N} @ 80 \mathrm{~kg} \mathrm{ha}^{-1}$ without the application of phosphatic fertilizer as compared to the treatments where no organic manure was added but $\mathrm{N} @ 120 \mathrm{~kg} \mathrm{ha}^{-1}$ and $\mathrm{P}_{2} \mathrm{O}_{5} @ 30 \mathrm{~kg} \mathrm{ha}^{-1}$ were applied to the rice crop. Also, the significantly higher concentration was observed in the treatments where organic manure @ $6 \mathrm{tha}^{-1}$ was added along with $\mathrm{N} @ 80 \mathrm{~kg} \mathrm{ha}^{-1}$ and $\mathrm{P}_{2} \mathrm{O}_{5} @ 30 \mathrm{~kg}$ $\mathrm{ha}^{-1}$ applied to the rice crop as compared to the treatments where no organic manure was incorporated but $\mathrm{N} @ 120 \mathrm{~kg} \mathrm{ha}^{-1}$ and $\mathrm{P}_{2} \mathrm{O}_{5}$ @ $30 \mathrm{~kg} \mathrm{ha}^{-1}$ were applied to the rice crop. Whereas in the wheat crop, the different levels of $\mathrm{P}_{2} \mathrm{O}_{5}\left(0,30\right.$ and $\left.60 \mathrm{~kg} \mathrm{ha}^{-1}\right)$ were applied, a significant response was observed in concentration of total $\mathrm{Mn}$ at these levels.

Table.1 Treatment details of long-term experiment on rice-wheat cropping system

\begin{tabular}{|c|c|c|c|c|}
\hline \multirow{2}{*}{ Treatments } & \multicolumn{3}{|c|}{ Rice } & Wheat \\
\cline { 2 - 5 } & $\begin{array}{c}\text { Manure } \\
\left(\mathrm{t} \mathrm{ha}^{-1}\right)\end{array}$ & $\mathrm{N}$ & $\mathrm{P}_{2} \mathrm{O}_{5}$ & $\begin{array}{c}\mathrm{P}_{2} \mathrm{O}_{5} \\
\left(\mathrm{~kg} \mathrm{ha}^{-1}\right)\end{array}$ \\
\hline $\mathrm{T}_{1}$ & 0 & 120 & 0 & 0 \\
\hline $\mathrm{T}_{2}$ & 0 & 120 & 0 & 30 \\
\hline $\mathrm{T}_{3}$ & 0 & 120 & 0 & 60 \\
\hline $\mathrm{T}_{4}$ & 6 & 80 & 30 & 0 \\
\hline $\mathrm{T}_{5}$ & 6 & 80 & 30 & 60 \\
\hline $\mathrm{T}_{6}$ & 6 & 80 & 30 & 0 \\
\hline $\mathrm{T}_{7}$ & 0 & 120 & 30 & 30 \\
\hline $\mathrm{T}_{8}$ & 0 & 120 & 30 & 0 \\
\hline $\mathrm{T}_{9}$ & 0 & 120 & 30 & 0 \\
\hline $\mathrm{T}_{10}$ & 6 & 80 & 0 & 60 \\
\hline $\mathrm{T}_{11}$ & 6 & 80 & 0 & 0 \\
\hline $\mathrm{T}_{12}$ & 6 & 80 & 0 & 0 \\
\hline
\end{tabular}

Table.2 Physico-chemical properties of experimental soil before sowing of wheat

\begin{tabular}{|l|c|}
\hline Parameter & Value \\
\hline Texture & Loamy sand \\
\hline $\mathrm{pH}(1: 2)$ & 6.71 \\
\hline $\mathrm{EC}\left(\mathrm{dSm}{ }^{-1}\right)$ & 0.17 \\
\hline Organic carbon $(\%)$ & 0.33 \\
\hline Available nitrogen $\left(\mathrm{kg} \mathrm{ha}^{-1}\right)$ & 275 \\
\hline Available phosphorus $\left(\mathrm{kg} \mathrm{ha}^{-1}\right)$ & 23 \\
\hline Available potassium $\left(\mathrm{kg} \mathrm{ha}^{-1}\right)$ & 184 \\
\hline Total zinc $\left(\mathrm{mg} \mathrm{kg}^{-1}\right)$ & 26.46 \\
\hline Total copper $\left(\mathrm{mg} \mathrm{kg}^{-1}\right)$ & 6.62 \\
\hline Total iron $(\%)$ & 1.14 \\
\hline Total manganese $\left(\mathrm{mg} \mathrm{kg}^{-1}\right)$ & 186.4 \\
\hline
\end{tabular}


Table.3 Depth wise distribution of total $\mathrm{Zn}\left(\mathrm{mg} \mathrm{kg}^{-1}\right)$ under rice-wheat system

\begin{tabular}{|c|c|c|c|c|c|c|c|c|}
\hline \multirow{2}{*}{$\begin{array}{c}\text { Treatments of } \\
\text { rice }\end{array}$} & \multicolumn{3}{|c|}{ Rates of $\mathrm{P}$ applied to wheat $\left(\mathrm{kg} \mathrm{P}_{2} \mathrm{O}_{5} \mathrm{ha}^{-1}\right)$} & \multirow[b]{2}{*}{ Mean } & \multicolumn{3}{|c|}{ Rates of $\mathrm{P}$ applied to wheat $\left(\mathrm{kg} \mathrm{P}_{2} \mathrm{O}_{5} \mathrm{ha}^{-1}\right)$} & \multirow[b]{2}{*}{ Mean } \\
\hline & $\mathrm{P}_{0}$ & $\mathrm{P}_{30}$ & $\mathrm{P}_{60}$ & & $\mathrm{P}_{0}$ & $\mathrm{P}_{30}$ & $\mathrm{P}_{60}$ & \\
\hline \multicolumn{5}{|c|}{$0-15 \mathrm{~cm}$} & \multicolumn{4}{|c|}{$60-90 \mathrm{~cm}$} \\
\hline$M_{0} \mathbf{N}_{120} P_{0}$ & 51.37 & 50.60 & 50.93 & 50.97 & 23.40 & 22.10 & 21.20 & 22.23 \\
\hline$M_{6} \mathbf{N}_{80} P_{30}$ & 53.03 & 53.40 & 50.67 & 52.37 & 24.33 & 23.60 & 23.67 & 23.87 \\
\hline $\mathbf{M}_{0} \mathbf{N}_{120} \mathbf{P}_{30}$ & 49.13 & 47.87 & 46.47 & 47.82 & 23.83 & 23.00 & 20.10 & 22.31 \\
\hline$M_{6} N_{80} P_{0}$ & 55.70 & 54.92 & 54.20 & 54.94 & 26.97 & 25.67 & 25.17 & 25.93 \\
\hline Mean & 52.31 & 51.70 & 50.57 & 51.52 & 24.63 & 23.59 & 22.53 & 23.58 \\
\hline LSD $(p<0.05)$ & \multicolumn{4}{|c|}{$\mathrm{R}=1.39, \mathrm{~W}=0.96, \mathrm{RxW}=\mathrm{NS}$} & \multicolumn{4}{|c|}{$\mathrm{R}=1.62, \mathrm{~W}=0.89, \mathrm{RxW}=\mathrm{NS}$} \\
\hline \multicolumn{5}{|c|}{$15-30 \mathrm{~cm}$} & \multicolumn{4}{|c|}{$90-120 \mathrm{~cm}$} \\
\hline$M_{0} \mathbf{N}_{120} P_{0}$ & 30.00 & 28.50 & 28.20 & 28.90 & 21.10 & 22.67 & 22.17 & 21.98 \\
\hline $\mathbf{M}_{6} \mathbf{N}_{80} \mathbf{P}_{30}$ & 32.03 & 30.50 & 30.27 & 30.93 & 25.47 & 25.47 & 23.47 & 24.80 \\
\hline $\mathbf{M}_{0} \mathbf{N}_{120} \mathbf{P}_{30}$ & 28.77 & 27.87 & 34.07 & 30.23 & 22.13 & 22.33 & 21.07 & 21.84 \\
\hline $\mathbf{M}_{6} \mathbf{N}_{80} P_{0}$ & 36.30 & 33.70 & 33.40 & 34.47 & 27.27 & 24.90 & 28.27 & 26.81 \\
\hline Mean & 31.78 & 30.14 & 31.48 & 31.13 & 23.99 & 23.84 & 23.74 & 23.85 \\
\hline LSD $(p<0.05)$ & \multicolumn{4}{|c|}{$\mathrm{R}=2.04, \mathrm{~W}=\mathrm{NS}, \mathrm{R} \times \mathrm{W}=3.60$} & \multicolumn{4}{|c|}{$\mathrm{R}=1.30, \mathrm{~W}=\mathrm{NS}, \mathrm{R} x \mathrm{~W}=\mathrm{NS}$} \\
\hline \multicolumn{5}{|c|}{$30-60 \mathrm{~cm}$} & \multicolumn{4}{|c|}{$120-150 \mathrm{~cm}$} \\
\hline$M_{0} \mathbf{N}_{120} P_{0}$ & 26.67 & 26.47 & 24.50 & 25.88 & 24.43 & 22.60 & 24.43 & 23.82 \\
\hline$M_{6} \mathbf{N}_{80} P_{30}$ & 27.07 & 26.63 & 26.85 & 26.85 & 25.00 & 24.83 & 24.33 & 24.72 \\
\hline $\mathbf{M}_{0} \mathbf{N}_{120} \mathbf{P}_{30}$ & 24.63 & 21.90 & 20.60 & 22.38 & 22.73 & 22.17 & 30.87 & 25.26 \\
\hline$M_{6} N_{80} P_{0}$ & 29.37 & 26.70 & 26.60 & 27.56 & 29.47 & 28.93 & 25.40 & 27.93 \\
\hline Mean & 26.93 & 25.43 & 24.64 & 25.66 & 25.41 & 24.63 & 26.26 & 25.43 \\
\hline $\operatorname{LSD}(p<0.05)$ & \multicolumn{4}{|c|}{$\mathrm{R}=1.30, \mathrm{~W}=0.83, \mathrm{RxW}=1.65$} & \multicolumn{4}{|c|}{$\mathrm{R}=2.33, \mathrm{~W}=\mathrm{NS}, \mathrm{RxW}=3.13$} \\
\hline
\end{tabular}


Table.4 Depth wise distribution of total $\mathrm{Cu}\left(\mathrm{mg} \mathrm{kg}^{-1}\right)$ under rice-wheat system

\begin{tabular}{|c|c|c|c|c|c|c|c|c|}
\hline \multirow{2}{*}{$\begin{array}{c}\text { Treatments of } \\
\text { rice }\end{array}$} & \multicolumn{3}{|c|}{ Rates of $\mathrm{P}$ applied to wheat $\left(\mathrm{kg} \mathrm{P}_{2} \mathrm{O}_{5} \mathrm{ha}^{-1}\right)$} & \multirow[b]{2}{*}{ Mean } & \multicolumn{3}{|c|}{ Rates of $\mathrm{P}$ applied to wheat $\left(\mathrm{kg} \mathrm{P}_{2} \mathrm{O}_{5} \mathrm{ha}^{-1}\right)$} & \multirow[b]{2}{*}{ Mean } \\
\hline & $\mathrm{P}_{0}$ & $\mathrm{P}_{30}$ & $\mathrm{P}_{60}$ & & $\mathrm{P}_{0}$ & $\mathrm{P}_{30}$ & $\mathrm{P}_{60}$ & \\
\hline \multicolumn{5}{|c|}{$0-15 \mathrm{~cm}$} & \multicolumn{4}{|c|}{$60-90 \mathrm{~cm}$} \\
\hline $\mathbf{M}_{0} \mathbf{N}_{120} \mathbf{P}_{0}$ & 7.70 & 7.64 & 7.43 & 7.59 & 9.60 & 9.48 & 9.57 & 9.55 \\
\hline $\mathbf{M}_{6} \mathbf{N}_{80} \mathbf{P}_{30}$ & 8.29 & 8.27 & 7.88 & 8.14 & 9.73 & 9.73 & 9.39 & 9.62 \\
\hline $\mathbf{M}_{0} \mathbf{N}_{120} \mathbf{P}_{30}$ & 7.63 & 7.44 & 7.20 & 7.42 & 8.97 & 9.23 & 9.01 & 9.07 \\
\hline $\mathbf{M}_{6} \mathbf{N}_{80} P_{0}$ & 9.43 & 9.23 & 8.23 & 8.97 & 9.93 & 9.40 & 9.33 & 9.56 \\
\hline Mean & 8.26 & 8.14 & 7.69 & 8.03 & 9.56 & 9.46 & 9.32 & 9.44 \\
\hline LSD $(p<0.05)$ & \multicolumn{4}{|c|}{$\mathrm{R}=0.17, \mathrm{~W}=0.15, \mathrm{RxW}=0.29$} & \multicolumn{4}{|c|}{$\mathrm{R}=0.36, \mathrm{~W}=\mathrm{NS}, \mathrm{RxW}=\mathrm{NS}$} \\
\hline \multicolumn{5}{|c|}{$15-30 \mathrm{~cm}$} & \multicolumn{4}{|c|}{$90-120 \mathrm{~cm}$} \\
\hline $\mathbf{M}_{0} \mathbf{N}_{120} \mathbf{P}_{0}$ & 8.87 & 8.77 & 8.67 & 8.77 & 9.47 & 9.33 & 8.97 & 9.25 \\
\hline $\mathbf{M}_{6} \mathbf{N}_{80} \mathbf{P}_{30}$ & 10.32 & 9.77 & 9.47 & 9.85 & 9.57 & 9.87 & 9.17 & 9.54 \\
\hline $\mathbf{M}_{0} \mathbf{N}_{120} \mathbf{P}_{30}$ & 8.10 & 7.68 & 7.87 & 7.88 & 9.20 & 8.77 & 9.30 & 9.09 \\
\hline$M_{6} N_{80} P_{0}$ & 9.67 & 9.74 & 9.77 & 9.72 & 9.60 & 9.36 & 9.30 & 9.42 \\
\hline Mean & 9.24 & 8.99 & 8.94 & 9.05 & 9.46 & 9.33 & 9.18 & 9.32 \\
\hline $\operatorname{LSD}(p<0.05)$ & \multicolumn{4}{|c|}{$\mathrm{R}=0.27, \mathrm{~W}=\mathrm{NS}, \mathrm{RxW}=\mathrm{NS}$} & \multicolumn{4}{|c|}{$\mathrm{R}=\mathrm{NS}, \mathrm{W}=\mathrm{NS}, \mathrm{R} \times \mathrm{W}=\mathrm{NS}$} \\
\hline \multicolumn{5}{|c|}{$30-60 \mathrm{~cm}$} & \multicolumn{4}{|c|}{$120-150 \mathrm{~cm}$} \\
\hline $\mathbf{M}_{0} \mathbf{N}_{120} \mathbf{P}_{0}$ & 8.43 & 9.57 & 9.23 & 9.08 & 9.33 & 8.97 & 9.63 & 9.31 \\
\hline $\mathbf{M}_{6} \mathbf{N}_{80} \mathbf{P}_{\mathbf{3 0}}$ & 9.53 & 9.30 & 9.37 & 9.40 & 9.73 & 9.40 & 9.10 & 9.41 \\
\hline $\mathbf{M}_{0} \mathbf{N}_{120} \mathbf{P}_{30}$ & 9.23 & 8.57 & 8.80 & 8.87 & 8.73 & 8.98 & 9.90 & 9.20 \\
\hline $\mathbf{M}_{6} \mathbf{N}_{80} P_{0}$ & 9.87 & 9.77 & 9.50 & 9.71 & 9.63 & 9.67 & 9.93 & 9.74 \\
\hline Mean & 9.27 & 9.30 & 9.22 & 9.26 & 9.36 & 9.25 & 9.64 & 9.41 \\
\hline $\operatorname{LSD}(p<0.05)$ & \multicolumn{4}{|c|}{$\mathrm{R}=0.55, \mathrm{~W}=\mathrm{NS}, \mathrm{RxW}=\mathrm{NS}$} & \multicolumn{4}{|c|}{$\mathrm{R}=\mathrm{NS}, \mathrm{W}=\mathrm{NS}, \mathrm{R} \times \mathrm{W}=\mathrm{NS}$} \\
\hline
\end{tabular}


Table.5 Depth wise distribution of total Fe (\%) under rice-wheat system

\begin{tabular}{|c|c|c|c|c|c|c|c|c|}
\hline \multirow[t]{2}{*}{$\begin{array}{l}\text { Treatments of } \\
\text { rice }\end{array}$} & \multicolumn{3}{|c|}{$\begin{array}{c}\text { Rates of } P \text { applied to wheat }\left(\mathrm{kg} \mathrm{P}_{2} \mathrm{O}_{5}\right. \\
\left.\mathrm{ha}^{-1}\right)\end{array}$} & \multirow[t]{2}{*}{ Mean } & \multicolumn{3}{|c|}{ Rates of $\mathrm{P}$ applied to wheat $\left(\mathrm{kg} \mathrm{P}_{2} \mathrm{O}_{5} \mathrm{ha}^{-1}\right)$} & \multirow[t]{2}{*}{ Mean } \\
\hline & $\mathrm{P}_{0}$ & $\mathrm{P}_{30}$ & $\mathrm{P}_{60}$ & & $\mathrm{P}_{0}$ & $\mathrm{P}_{30}$ & $\mathrm{P}_{60}$ & \\
\hline \multicolumn{5}{|c|}{$0-15 \mathrm{~cm}$} & \multicolumn{4}{|c|}{$60-90 \mathrm{~cm}$} \\
\hline $\mathbf{M}_{0} \mathbf{N}_{120} \mathbf{P}_{0}$ & 1.43 & 1.38 & 1.37 & 1.39 & 1.60 & 1.63 & 1.63 & 1.62 \\
\hline $\mathbf{M}_{6} \mathbf{N}_{80} \mathbf{P}_{30}$ & 1.47 & 1.45 & 1.43 & 1.45 & 1.64 & 1.64 & 1.67 & 1.65 \\
\hline $\mathbf{M}_{0} \mathbf{N}_{120} \mathbf{P}_{30}$ & 1.33 & 1.37 & 1.25 & 1.31 & 1.57 & 1.59 & 1.62 & 1.59 \\
\hline $\mathbf{M}_{6} \mathbf{N}_{80} P_{0}$ & 1.51 & 1.49 & 1.48 & 1.49 & 1.67 & 1.69 & 1.73 & 1.70 \\
\hline Mean & 1.43 & 1.42 & 1.38 & 1.41 & 1.62 & 1.64 & 1.66 & 1.64 \\
\hline $\operatorname{LSD}(p<0.05)$ & \multicolumn{4}{|c|}{$\mathrm{R}=\mathrm{NS}, \mathrm{W}=\mathrm{NS}, \mathrm{RxW}=\mathrm{NS}$} & \multicolumn{4}{|c|}{$\mathrm{R}=0.02, \mathrm{~W}=0.01, \mathrm{RxW}=\mathrm{NS}$} \\
\hline \multicolumn{5}{|c|}{$15-30 \mathrm{~cm}$} & \multicolumn{4}{|c|}{$90-120 \mathrm{~cm}$} \\
\hline $\mathbf{M}_{0} \mathbf{N}_{120} \mathbf{P}_{0}$ & 1.44 & 1.45 & 1.44 & 1.44 & 1.60 & 1.61 & 1.63 & 1.62 \\
\hline $\mathbf{M}_{6} \mathbf{N}_{80} \mathbf{P}_{30}$ & 1.45 & 1.46 & 1.49 & 1.47 & 1.66 & 1.65 & 1.67 & 1.66 \\
\hline $\mathbf{M}_{0} \mathbf{N}_{120} \mathbf{P}_{30}$ & 1.40 & 1.41 & 1.43 & 1.42 & 1.56 & 1.58 & 1.60 & 1.58 \\
\hline $\mathbf{M}_{6} \mathbf{N}_{80} P_{0}$ & 1.50 & 1.53 & 1.55 & 1.53 & 1.69 & 1.72 & 1.74 & 1.71 \\
\hline Mean & 1.45 & 1.46 & 1.48 & 1.46 & 1.63 & 1.64 & 1.66 & 1.64 \\
\hline $\operatorname{LSD}(p<0.05)$ & \multicolumn{4}{|c|}{$\mathrm{R}=0.02, \mathrm{~W}=0.02, \mathrm{RxW}=\mathrm{NS}$} & \multicolumn{4}{|c|}{$\mathrm{R}=0.01, \mathrm{~W}=0.01, \mathrm{RxW}=\mathrm{NS}$} \\
\hline \multicolumn{5}{|c|}{$30-60 \mathrm{~cm}$} & \multicolumn{4}{|c|}{$120-150 \mathrm{~cm}$} \\
\hline $\mathbf{M}_{0} \mathbf{N}_{120} \mathbf{P}_{0}$ & 1.54 & 1.54 & 1.56 & 1.55 & 1.70 & 1.70 & 1.73 & 1.71 \\
\hline $\mathbf{M}_{6} \mathbf{N}_{80} \mathbf{P}_{30}$ & 1.57 & 1.58 & 1.62 & 1.59 & 1.74 & 1.74 & 1.76 & 1.75 \\
\hline $\mathbf{M}_{0} \mathbf{N}_{120} \mathbf{P}_{30}$ & 1.45 & 1.48 & 1.52 & 1.48 & 1.64 & 1.66 & 1.67 & 1.66 \\
\hline$M_{6} N_{80} P_{0}$ & 1.63 & 1.63 & 1.65 & 1.64 & 1.78 & 1.79 & 1.81 & 1.79 \\
\hline Mean & 1.55 & 1.56 & 1.59 & 1.56 & 1.72 & 1.72 & 1.74 & 1.72 \\
\hline $\operatorname{LSD}(p<0.05)$ & \multicolumn{4}{|c|}{$\mathrm{R}=0.02, \mathrm{~W}=0.01, \mathrm{RxW}=\mathrm{NS}$} & \multicolumn{4}{|c|}{$\mathrm{R}=0.02, \mathrm{~W}=0.01, \mathrm{RxW}=\mathrm{NS}$} \\
\hline
\end{tabular}


Table.6 Depth wise distribution of total $\mathrm{Mn}\left(\mathrm{mg} \mathrm{kg}^{-1}\right)$ under rice-wheat system

\begin{tabular}{|c|c|c|c|c|c|c|c|c|}
\hline \multirow{2}{*}{$\begin{array}{c}\text { Treatments of } \\
\text { rice }\end{array}$} & \multicolumn{3}{|c|}{ Rates of $\mathrm{P}$ applied to wheat $\left(\mathrm{kg} \mathrm{P}_{2} \mathrm{O}_{5} \mathrm{ha}^{-1}\right)$} & \multirow[t]{2}{*}{ Mean } & \multicolumn{3}{|c|}{ Rates of $P$ applied to wheat $\left(\mathrm{kg} \mathrm{P}_{2} \mathrm{O}_{5} \mathrm{ha}^{-1}\right)$} & \multirow[t]{2}{*}{ Mean } \\
\hline & $\mathrm{P}_{0}$ & $\mathrm{P}_{30}$ & $\mathrm{P}_{60}$ & & $\mathrm{P}_{0}$ & $\mathrm{P}_{30}$ & $\mathrm{P}_{60}$ & \\
\hline \multicolumn{5}{|c|}{$0-15 \mathrm{~cm}$} & \multicolumn{4}{|c|}{$60-90 \mathrm{~cm}$} \\
\hline $\mathbf{M}_{0} \mathbf{N}_{120} \mathbf{P}_{0}$ & 216.3 & 215.7 & 213.7 & 215.2 & 332.5 & 331.5 & 327.7 & 330.6 \\
\hline$M_{6} \mathbf{N}_{80} P_{30}$ & 217.2 & 215.7 & 217.1 & 216.7 & 337.0 & 335.8 & 334.3 & 335.7 \\
\hline $\mathbf{M}_{0} \mathbf{N}_{120} \mathbf{P}_{30}$ & 210.1 & 205.3 & 203.6 & 206.4 & 321.2 & 317.0 & 316.5 & 318.2 \\
\hline $\mathbf{M}_{6} \mathbf{N}_{80} \mathbf{P}_{0}$ & 219.8 & 218.8 & 218.7 & 219.1 & 345.3 & 343.3 & 340.4 & 343.0 \\
\hline Mean & 215.8 & 213.9 & 213.3 & 214.3 & 334.0 & 331.9 & 329.7 & 331.8 \\
\hline $\operatorname{LSD}(p<0.05)$ & \multicolumn{4}{|c|}{$\mathrm{R}=0.95, \mathrm{~W}=0.92, \mathrm{RxW}=1.84$} & \multicolumn{4}{|c|}{$\mathrm{R}=1.30, \mathrm{~W}=1.03, \mathrm{RxW}=\mathrm{NS}$} \\
\hline \multicolumn{5}{|c|}{$15-30 \mathrm{~cm}$} & \multicolumn{4}{|c|}{$90-120 \mathrm{~cm}$} \\
\hline $\mathbf{M}_{0} \mathbf{N}_{120} \mathbf{P}_{0}$ & 290.4 & 293.2 & 295.5 & 293.0 & 349.1 & 346.5 & 342.8 & 346.1 \\
\hline$M_{6} N_{80} P_{30}$ & 297.4 & 299.6 & 303.3 & 300.1 & 352.7 & 350.8 & 349.6 & 351.0 \\
\hline $\mathbf{M}_{0} \mathbf{N}_{120} \mathbf{P}_{30}$ & 285.5 & 289.2 & 288.0 & 287.6 & 340.3 & 338.3 & 332.7 & 337.1 \\
\hline $\mathbf{M}_{6} \mathbf{N}_{80} \mathbf{P}_{0}$ & 305.3 & 303.7 & 302.3 & 303.8 & 360.9 & 358.3 & 354.8 & 358.0 \\
\hline Mean & 294.7 & 296.4 & 297.3 & 296.1 & 350.8 & 348.5 & 344.9 & 348.1 \\
\hline $\operatorname{LSD}(p<0.05)$ & \multicolumn{4}{|c|}{$\mathrm{R}=1.04, \mathrm{~W}=0.97, \mathrm{RxW}=1.95$} & \multicolumn{4}{|c|}{$\mathrm{R}=1.41, \mathrm{~W}=1.01, \mathrm{R} \times \mathrm{W}=\mathrm{NS}$} \\
\hline \multicolumn{5}{|c|}{$30-60 \mathrm{~cm}$} & \multicolumn{4}{|c|}{$120-150 \mathrm{~cm}$} \\
\hline $\mathbf{M}_{0} \mathbf{N}_{120} \mathbf{P}_{0}$ & 310.8 & 306.9 & 305.5 & 307.7 & 373.9 & 370.7 & 371.8 & 372.1 \\
\hline$M_{6} \mathbf{N}_{80} P_{30}$ & 317.1 & 316.5 & 313.7 & 315.8 & 382.3 & 379.9 & 376.5 & 379.6 \\
\hline $\mathbf{M}_{0} \mathbf{N}_{120} \mathbf{P}_{30}$ & 304.8 & 299.1 & 297.2 & 300.4 & 367.5 & 364.5 & 363.6 & 365.2 \\
\hline$M_{6} N_{80} P_{0}$ & 326.4 & 324.3 & 321.3 & 323.9 & 386.5 & 384.5 & 384.6 & 385.2 \\
\hline Mean & 314.8 & 311.7 & 309.3 & 311.9 & 377.6 & 374.9 & 374.1 & 375.5 \\
\hline $\operatorname{LSD}(p<0.05)$ & \multicolumn{4}{|c|}{$\mathrm{R}=1.50, \mathrm{~W}=1.59, \mathrm{RxW}=\mathrm{NS}$} & \multicolumn{4}{|c|}{$\mathrm{R}=1.93, \mathrm{~W}=1.08, \mathrm{RxW}=\mathrm{NS}$} \\
\hline
\end{tabular}


The interaction between rice and wheat treatments is observed as significant. Similar results were observed by Sharma et al., (2000) and Lu et al., (2004), who reported that the continuous use of rice-wheat cropping system year after year reduced the Mn due to leaching down to lower depth of soil.

Vitamin $\mathrm{C}$ content in different hoblies of different district of Karnataka is tabulated in table 2. Vitamin $\mathrm{C}$ content was significantly high in almost all the hoblies of Shimoga district. Banagi and Muturu hobli were having (1056.82 and 1056.81ppm) of vitamin C content and followed by kasaba hobli of Hosanagara taluk (1056.77ppm), Talaguppa hobli (1056.66ppm) and kasaba hobli of Bhadravathi taluk (1056.55ppm). Less concentration was identified in kasaba hobli of Shimoga taluk 352.11ppm, nidige hobli $352.33 \mathrm{ppm}$ respectively.

In Chikkamagalur district, more vitamin c content was found in Kasaba hobli of Sringeri taluk (1056.84ppm), Kalasa and Kasaba hobli of Mudigere taluk had 1056.53 and 1056.51ppm of vitamin C content and less concentration was estimated in Lakya and khandya hobli of Chikkamagalur taluk (528.22 and 528.68ppm), and Kasaba hobli of Narasimharajapura taluk (528.67ppm).

There was no significant difference of vitamin $\mathrm{C}$ content in Davangere district. The vitamin $\mathrm{c}$ ion concentration was similar in Santhebennuru and Anagodu hobli (1056.33ppm). In Kasaba hobli of Honnali taluk and in Belaguthi hobli vitamin $\mathrm{C}$ content was found to be (1056.50 and 1056.74ppm).

In Chitradurga district there was a significant variation of vitamin $\mathrm{C}$ content. The highest concentration of vitamin $\mathrm{C}$ was found in Kasaba hobli of Holalkere taluk (792.63ppm) and less content was observed in Ramagiri hobli (264.56ppm) and followed by Imangala hobli, Hireguntanuru hobli $(264.75 \mathrm{ppm}$ and 264.79ppm).

In Kadaba hobli of Dakshina kannada district were having more concentration of vitamin $\mathrm{C}$ content (792.79ppm), and followed by Bantwala and vitla hobli (792.52 and 792.50ppm) and Mangaluru B and Mudabidre were having less content of vitamin $\mathrm{C}$ (264.75 and 264.56ppm). In Udupi district high concentration of vitamin $\mathrm{C}$ was identified in Kota hobli (792.22ppm) and less content was found in Vandse hobli 264.37ppm and followed by Ajekaru and Karkalla hobli of karakala taluk (264.55ppm and 264.56ppm).

Vitamin $\mathrm{B}_{6}$, also called pyridoxine, is a watersoluble nutrient that is part of the $\mathrm{B}$ vitamin family. B vitamins, including vitamin B6, help support adrenal function, help calm and maintain a healthy nervous system, and are necessary for key metabolic processes.

Vitamin B6 acts as a coenzyme in the breakdown and utilisation of carbohydrates, fats and proteins. Vitamin $\mathrm{B}_{6}$ helps in the production of neurotransmitters, the chemicals that allow brain and nerve cells to communicate with one another, ensuring that metabolic processes such as fat and protein metabolism run smoothly, and is important for the functioning of immune system in older individuals.

The result of samples analysed for vitamin B6 from 117 locations of six important areca growing districts of Karnataka are presented in the table 1. In general, the contents of vitamin B6 ranged from 10 to $91 \mathrm{ppm}$. Higher vitamin B6 contents were in Anwatti (52.33), Kigga (72.67), Bilichodu (84.67), Turuvanooru (72.67), Uppinangadi (91.22) and Ajekaru (81.00) of Shimoga, Chikkamagaluru, Davanagere, Chitradurga, Dakshina kannada and Udupi districts 
respectively. It is interesting to notice that, in about 30 percent of locations the content of vitamin B6 was only $10 \mathrm{ppm}$. Talukwise variation was highly significant with a range of 10.24 to $88.38 \mathrm{ppm}$. Highest vitamin B6 was observed in samples of Puttur (88.38) followed by Karkala (67.98) and Hosadurga (56.44) whereas lowest concentration was in Hosanagara (10.21). The mean vitamin content was lowest in Shimoga district (15.68) and highest was in Dakshina Kannada district (50.49).

Regarding vitamin C contents, there were a significant differences among the hoblies of all the six districts of Karnataka. Vitamin content in different hoblies has been presented in table 3 . The samples of 8 hoblies viz. Alduru, Panchanahalli, Gonibidu, Balehonnuru, Basavapatna, Kasaba, Arsikere and Govinkovi contained highest vitamin $\mathrm{C}$ content of 1320 ppm but lower content was found in 10 hoblies viz. Hiregunturu, Imangala, Kasaba, Ramagiri, Mangaluru, Mudabidre, Ajekaru, Karkala, Kundapura and Vadse wherein its concentration was only 264 ppm. Highly significant variations existed in vitamin C content among all the 35 taluks of 6 districts (Table 4). Mean over all the taluks indicated that highest vitamin $\mathrm{C}$ content (1012 ppm) was in Davanagere district followed by Shimoga and Chikamagaluru districts (897 ppm). Similarly, Areca nut Research and Development Foundation (ARDF 2015), Sirsi have reported that, vitamin-A and vitamin B-6 were found in traces in areca nut samples of Karnataka.

The determination of vitamin B6, it should be noted that vitamin B6 are usually unstable and therefore the reference and sample protocols must be handled with great care while using HPLC. Separation and quantification should be done with a high level of precision and suitable methods. HPLC method for analysing vitamin B6 is common but a single run HPLC method for simultaneous analysis of vitamins are undocumented. It is therefore important to have a single most sensitive HPLC method, which is robust, rapid and efficient for determining all the water-soluble vitamins in a single run. Both hobli wise and taluk wise areca samples recorded highly significant variations in vitamin $\mathrm{B} 6$ contents with a range of 91.33 to $10.00 \mathrm{ppm}$.

\section{References}

Agbenin, J. O. and Henningsen. 2003. The distribution and transformation of iron and manganese in soil fraction in a savanna alfisol under continuous cultivation. NutrCyclAgroecosys66: 259-270.

Behera, S. K., Singh, D., Dwivedi, B. S., Singh, S., Kumar, K. and Rana, D. S. 2008. Distribution of fraction of zinc and their contribution towards availability and plant uptake of zinc under long-term maize (Zea mays L.) wheat (Triticum aestivum L.) cropping on an Inceptisol. Aust J Soil Res 46: 8389.

Behera, S. K., Singh, D. and Dwivedi, B. S. 2009. Changes in fractions of iron, manganese, copper and zinc in soil under continuous cropping for more than three decades. Commun Soil Sci Plant Anal 40: 1380-1407.

Dhaliwal, S. S.2008. Different chemical pools of $\mathrm{Mn}$ as influenced by submergence, green manure and soil applied Mn under rice- wheat system. Asian J Soil Sci 3(1): 94-98.

Dhaliwal, S. S. and Walia, S. S. 2008. Integrated nutrient management for sustaining maximum productivity of rice-wheat system under Punjab conditions. J Res PAU 45:12-16.

Dhaliwal, S. S, Sadana, U. S., Sidhu, S. S. and Gurpreet, S. 2011. Role of cropping systems in amelioration of aggravated 
micronutrients deficiency in alluvial soils of Punjab. J Pl Sci Res27: 21-29.

Elbordiny, M. M. and Camilia, Y. D. 2008. Effect of some salt affected soil properties on micronutrients availability. J Appl Sci Res 4(11): 1569-1573.

Herencia, J. F., Ruiz, J. C., Melero, M. S., Villaverde, J. and Maqueda, C. 2008. Effects of organic and mineral fertilization on micronutrient availability in soil. Soil Sci173: 69-80.

Khan, M. S. H., Mian, M. J., Akhtar, A., Hossain, M. F. and Sikder, M. S. I. 2002.Effects of long term fertilization and cropping on micronutrient cations of soils in Bangladesh. Pak J Biol Sci 5:543-544.

Lu, S., Liu, X., Li,L., Zhang, F., Zhang, X. and Tang, C. 2004.Effect of manganese spatial distribution in the soil profile on wheat growth in rice-wheat rotation.Pl Soil 261: 39-46.

Page, A. L., Miller, R. H. and Keeney, D. R. 1982. Methods of soil analysis. Part 2, $2^{\text {nd }}$ edition. Am Soc Agron, Madison, Wisconsin, USA.

Panse, V. G.and Sukhatme, P. V. 1985.Statistical methods for agricultural workers $4^{\text {th }}$ Edn. ICAR, New Delhi, pp 359.

Sharma, B. D., Harsh, A., Kumar, R. and Nayyar, V. K. 2004.Relationships between soil characteristics and total and DTPA-extractable micronutrients in
Inceptisols of Punjab. Commun Soil Sci Pl Anal 37: 799-818.

Sharma, M. P., Bali, S. V. and Gupta, D. K. 2000.Crop yield and properties of inceptisol as influenced by residue management under rice-wheat cropping sequence. J Indian Soc Soil Sci 48: 506509.

Singh, J. P., Karwasra, S. P. S. and Singh, M. 1988.Distribution and forms of copper, iron, manganese and zinc in calcareous soils of India. J Indian Soc Soil Sci146: 359-66.

Verma, A., Nepalia, V. and Kanthaliya, P. C. 2005a.Effect of decade long - term fertilizer and manure application on soil fertility and productivity of rice-wheat system in a Mollisol. J Indian Soc Soil Sci 53: 365-368.

Verma, V. K., Setia, R. K., Sharma, P. K., Singh, C. and Kumar, A. 2005b.Pedospheric Variations in distribution of DTPA- extractable micronutrients in soils developed on different physiographic units in central parts of Punjab, India. Int J Agri Biol 7(2): 243-246.

Zhang, L., He, M., Zhang, X. E. and Stoffela, P. J. 2008.Long term effect of manure application on micronutrient availability under rice-wheat and maize-wheat cropping systems. Soil Sci Soc Am J 70: 1699-1717.

\section{How to cite this article:}

Dhaliwal, M.K., S.S. Dhaliwa and Shukla, A.K. 2019. Long Term Effect of Manure and Fertilizers on Depthwise Distribution of Total $\mathrm{Zn}, \mathrm{Cu}, \mathrm{Fe}$ and $\mathrm{Mn}$ under Rice-Wheat System. Int.J.Curr.Microbiol.App.Sci. 8(01): 3179-3191. doi: https://doi.org/10.20546/ijcmas.2019.802.371 